Kansas State University Libraries

New Prairie Press

\title{
EFFECT ON BOLL WEIGHT OF COTTON PLANTS PLANTED AT VARIOUS DENSITIES
}
B. G. Mullinix
C. W. Bednarz

Follow this and additional works at: https://newprairiepress.org/agstatconference

Part of the Agriculture Commons, and the Applied Statistics Commons

\section{(c) (1) $\Theta($}

This work is licensed under a Creative Commons Attribution-Noncommercial-No Derivative Works 4.0 License.

\section{Recommended Citation}

Mullinix, B. G. and Bednarz, C. W. (2002). "EFFECT ON BOLL WEIGHT OF COTTON PLANTS PLANTED AT

VARIOUS DENSITIES," Conference on Applied Statistics in Agriculture. https://doi.org/10.4148/

2475-7772.1209

This is brought to you for free and open access by the Conferences at New Prairie Press. It has been accepted for inclusion in Conference on Applied Statistics in Agriculture by an authorized administrator of New Prairie Press. For more information, please contact cads@k-state.edu. 


\title{
EFFECT ON DOLL WEIGHT OF COTTON PLANTS PLANTED AT VARIOUS DENSTIES
}

\author{
B. G. Mullinix and C. W. Bednarz \\ Experimental Statistics Unit and Crop and Soil Science Department \\ College of Agricultural and Envirommental Sciences \\ University of Georgia - Tifton Campus \\ Tifton GA $31793-0748$
}

\begin{abstract}
Previous research has shown that yield of coton increases with plant density until density reaches 16 to 20 plants $\mathrm{m}^{-2}$. In 1997 and 1998 cotton was planted at various densities ranging from 2.5 to 22.5 plants $\mathrm{m}^{-2}$ in a RCB design. Ten row feet $(3.048 \mathrm{~m})$ of cotton were cut at ground level in each plot and placed into separate bags. Plant density for each plot was found by counting the number of plants in the bag representing that plot. For each plant, a boll found was placed in a small bag representing the fruiting branch and position from which it had been taken. A token was placed in the compartment which contained this bag. Any position without a harvestable boll was recorded as zero. Each small bag was weighed (total boll weight) and number of bolls were determined from the count of tokens thus providing mean boll weight. Mixed model analyses were performed on total yield, mean boll weight, and percent harvestable bolls; however, only mean boll weight will be presented. A response surface was determined for fruiting position by plant density.
\end{abstract}

\section{Introduction}

Cotton is an important crop in Georgia since almost 1.5 million acres were planted in 2001 producing 2.2 million bales ( $400 \mathrm{lbs}$ ) (Brown, 2002). This is about $8.4 \%$ of the total cotton produced in the United States. Cotton plant growth and development is regulated by available resources such as sunlight, water, and nutrition (Bednarz et al., 1998; Kerby, 1996). Availability of these resources is affected by other organisms living in the same area such as weeds, insects, or other cotton plants. The objective of most population studies is to determine the plant density that will result in utilization of all available resources with a minimal amount of interplant competition. A population density of 35 to 50 thousand plants acre ${ }^{-1}\left(8.65\right.$ to 12.35 plants $\left.\mathrm{m}^{-2}\right)$ in cotton is considered optimum. The sympodial fruiting branch (node) of cotton allows it to compensate for wide variations in stand density. Densities as low as 15 or as high as 60 thousand plants acre $\left(3.71\right.$ to 14.82 plants $\left.\mathrm{m}^{-2}\right)$ may be acceptable. However, different population densities will change the amount of resources available to each individual plant, which will change the level of interplant competition and the manner in which the crop develops. Bridge et al. (1973), Jenkins et al. (1990), and Kerby (1996) stated that crowding cotton plants will initiate earliness even if the cultivar planted is considered early maturing.

Interestingly, few if any population studies have been conducted with production costs in mind (Bednarz et al., 1998). The U.S. Farm Bill, rising production costs, and increased foreign competition have compelled agronomists to investigate management practices that will help reduce production costs. One such management practice may lie in the area of seeding rates and population densities. If seeding 
rates were reduced by one seed foot ${ }^{-1}$ of row, seed costs could be reduced by $\$ 2.78$ acre $^{-1}$ assuming $\$ 45.00 \mathrm{bag}^{-1}$ and $4,700 \mathrm{seed}^{-1} \mathrm{H}^{-1}$. Monsanto announced in 1998 technology fees will be placed on a bag of seed. Therefore a bag of BG/RR (Bollgard ${ }^{\mathrm{TM}}$ gene/Roundup Ready ${ }^{\mathrm{TM}}$ gene) cottonseed will cost $\$ 238.50$ $\mathrm{bag}^{-1}$. If transgenic seeding rates were reduced by one seed foot ${ }^{-1}$ of row, seed costs would be reduced by $\$ 14.76$ acre ${ }^{-1}$ assuming 4,700 seed $1 \mathrm{~b}^{-1}$. The purpose of this study was to determine the lowest possible seeding rate in cotton that will not result in significant reductions in lint yield or lint quality and to investigate changes in growth and development of the crop under resulting population densities. Also, at secondary purpose was to find the seeding rate where seedcotton yicld no longer is increasing.

\section{Spatial Distribution of Bols on the Cotton Plant}

Jenkins et al. (1990) examined the distribution of cotton yield on eight cultivars (ST 213, ST 506, ST 825, CAMD-E, DPL 50 MC 235, DES 119, DPL 20) by node and position. Cotton was planted at 95 plants $\mathrm{m}^{-2}$. A node refers to any sympodial fruiting branch on which a boll may occur. Lower nodes are usually called monopodium (vegetative) branches because they look like miniature main stems. Upper nodes are called sympodium (fruiting) branches where one or more bolls appear one at each fruiting site. Vegetative bolls may also appear where the sympodial branch connects to the main stem, or in rare cases. on the opposite side of the main stem. Cultivars varied from $51 \%$ (nodes $10-14$ ) to $69 \%$ (nodes $8-14$ ) to $75 \%$ (nodes $8-15$ ) in total lint yield. The same three cultivars varied $73.5 \%$ to $69.2 \%$ to $72.5 \%$ lint yield on first position bolls compared with total lint yieds for the same nodes.

Kerby (1996) showed from data collected at numerous locations that $51 \%$ of the bolls were in nodes $8-12$ for the first position, $52.7 \%$ were for all positions, and $66.3 \%$ of all boles in nodes $8-12$ were first position bolls. Second position bolls occurred from node 5 through 20 , while thitd position bolls occurred from node 6 through 16.

There have been at least nine published studies involving the effect of population density on the lint yield of coton (Hawkins and Peacock, 1970; 1973; Fowler and Ray, 1997, Kerby et al., 1990; Jones and Wells, 1997; Hicks et al., 1989; Bridge ef al., 1973; Smith et al. 1979; Culp et al., 1974).

Hawkins and Peacock (1970) conducted population density trials for three years. Densities ranged from 3.2 to 24.1 plants $\mathrm{m}^{-2}$. Maximum lint yield occurred at 14.9 plants $\mathrm{m}^{-2}$ in $1964,1019.7$ plants $\mathrm{m}^{-2}$ in 1967 , and 17.3 plants $\mathrm{m}^{-2}$ in 1968 .

Hawkins and Peacock (1973) conducted three population density trials in 1970 and 1971 at two densities $\left(12.8\right.$ and 25.6 plants $\left.\mathrm{m}^{-2}\right)$ with four row width $(25.4,50.8,76.2$, and $101.6 \mathrm{~cm})$. They reported no difference between the two densities, but found an effect due to row width. However, viewing the means of trial, density, and row width would suggest that trial 2 was unusually erratic which would negate any row widh effects. Boll weight showed no response to either density or row width. Estimated calculus values for density show that 16.24 plants $\mathrm{m}^{-2}$ to be a minimum for lint yield, while 10.93 to be a maximum for boll weight.

Fowler and Ray (1997) conducted a population density trial on two cultivars, Paymaster 101A was early maturing and well adapted to western Texas, while C.A. 491 was selected because of its response to high density trials and earlier fruiting. Population densities examined ranged from 3.875 to 62.0 plants $\mathrm{m}^{-2}$. Maximum lint yield using $\log _{10}$ density occurred at 9.6 plants $\mathrm{m}^{-2}$ for Paymaster $101 \mathrm{~A}$ and 14.9 plants $m^{-2}$ for C.A. 491.

Kerby et al. (1990) conducted population density trials in 1984 and 1985 on five cultivars: 'Acala SI-2' was most indeterminate and tallest, 'Acala SJC-1' and Shafter genotype 2218 were moderate determinacy and height, and Shafter genotypes 2280 and 2086 were least indeterminate and shortest. Population densities tested were 5,10 , and 15 plants $\mathrm{m}^{-2}$. The calculus on density for lint yields were 9.2 plants $\mathrm{m}^{-2}$ for 'Acala SJ-2' ( $\left.\mathrm{max}\right), 11.3$ plants $\mathrm{m}^{-2}$ for 'Acala SIC-I' (min), 14.9 plants $\mathrm{m}^{-2}$ for Shafter 
genotype $2218(\mathrm{~min}), 18.7$ plants $\mathrm{m}^{-2}$ for Shafter genotype $2280(\max )$, and 16.25 plants $\mathrm{m}^{-2}$ for Shafter genotype $2086(\mathrm{max})$. The calculus on density for percent total bolls (mean of five cultivars) on nodes 9 12 was 9.6 plants $\mathrm{m}^{-2}$ ( $\left.\max \right)$, for percent total bolls on nodes $13-20$ was 7.8 plants $\mathrm{m}^{-2}$ ( $\mathrm{min}$ ), and for percent total first position bolls on all nodes was 16.3 plants $\mathrm{m}^{-2}(\max )$. As plant density increased from 5 to 10 plants $\mathrm{m}^{-2}$ there was a tendency for percent bolls to shift from nodes below number nine to nodes $9-$ 12. When density increased from 10 to 15 plants $\mathrm{m}^{-2}$ there was a tendency for percent total bolls to shift from nodes below number thirteen to nodes 13-20. At both increases of plant density, percent total bolls shifted to the first position: $48.3-64.2 \%$ (on nodes $5-10$ ) and $64.2-71.1 \%$ (on nodes $10-15)$.

Jones and Wells (1997) conducted population density trials for two years $(1992,1993)$ at two densities ( 2 and 12 plants $\mathrm{m}^{-2}$ ). Numbers of mature bolls were greater at day 95 (1992) and at day 87 (1993) for the density of 12 plants $\mathrm{m}^{-2}$, while cumulative number of mature bolls remained higher throughout the season for both years. At the lower density, number of mature bolls was spread out among the nodes $1-20(1992)$ and nodes $1-15(1993)$. At the higher density, number of mature bolls were concentrated among nodes $6-15$ (1992) and nodes 6-10 (1993). This indicates that fruting is concentrating among the center nodes. At the lower density the percent mature bolls at the first position were $23,4 \%$ (1992) and $21.0 \%(1993)$. At the higher density the percent mature bolls at the first position were $80.5 \%$ (1992) and $86.3 \%(1993)$. This indicates that fruiting is rapidly concentrating near the main siem.

Hicks et al. (1989) conducted population density trials in 1986 and 1987 with two cultivars ('Acala A246' and 'Paymater 404'). The calculus on density lint yield was 10.7 plants $\mathrm{m}^{-2}$ ( $\max$ ) for 'Acala A246' in 1986 and 4.73 plants $\mathrm{m}^{-2}(\max )$ in 1987; and 20.5 plants $\mathrm{m}^{-2}$ ( $\max$ ) for 'Paymaster 404 ' in 1986 and 5.35 plants $\mathrm{m}^{-2}$ (min) in 1987.

Bridge et al. (1973) conducted a three year study (1969-1971) involving two methods of planting the cotton: Hill where hills were $38 \mathrm{~cm}$ apart with either $1,3,5,7$, or 9 plants hill $^{-1}$ (2.46 to 18.65 plants $\left.\mathrm{m}^{-2}\right)$; and Row where in-row spacing of plants were $38.0,12.7,7.6,5.3$, or $4.3 \mathrm{~cm}(2.71$ to 22.41 plants $\mathrm{m}$ 2). Maximum lint yields occurred at 13.35 plants $\mathrm{m}^{-2}$ for total and 13.81 plants $\mathrm{m}^{-2}$ for first-pick (FP) in 1969 for the Hill planting method; 7.09 plants $\mathrm{m}^{-2}$ for total and 8.17 plants $\mathrm{m}^{-2}$ for FP in 1970 ; and 11.16 plants $\mathrm{m}^{-2}$ for total and 11.16 plants $\mathrm{m}^{-2}$ for FP in 1971 . Maximum lint yields occurred at 13.98 plants $\mathrm{m}^{-2}$ for total and 14.07 plants $\mathrm{m}^{-2}$ for first-pick (FP) in 1969 for the Row planting method; 11.40 plants $\mathrm{m}^{-2}$ for total and 12.02 plants $\mathrm{m}^{-2}$ for $\mathrm{FP}$ in 1970; and 12.64 plants $\mathrm{m}^{-2}$ for total and 13.27 plants $\mathrm{m}^{-2}$ for $\mathrm{FP}$ in 1971. The maximum yield calculus for density would have been overestimated had only the first-pick lint yields been evaluated which indicates that maturing early may be a consequence of excessive plant crowding.

Smith et al. (1979) conducted a population study involving two years $(1975,1976)$ and 3 cultivars ('Quapaw, 'Rex 713', 'DPL 16'). Population densities examined were 3.4, 10.2, and 17.0 plants $\mathrm{m}^{-2}$. Maximum lint yield occurred at 11.31 plants $\mathrm{m}^{-2}$.

Baker (1976) conducted a population density study involving three years (1971.1973) with two row patterns (two twin rows spaced at either 25.4 or $40.6 \mathrm{~cm}$ ) and three population densities $(21.5,28.7$, 35.8 plants $\mathrm{m}^{-2}$ ). There was no difference in lint yield in response to either row pattern or density or when compared with the traditional two row planting $(91.4 \mathrm{~cm}$ apart). Lint yield was increasing with the highest density in the ultra-narrow twin rows and had leveled off in the wider twin rows. The only reported response was the abundance of blooms on the highest density in the ultra-narrow twin rows, but bloom counts had declined at the highest density in the wider twin rows.

Culp et al. (1974) conducted two studies which examined the effect of population density on cotton lint production. The first study involved planting cotton in hills $35.6 \mathrm{~cm}$ apart and the rows were $101.6 \mathrm{~cm}$ apart. Four rows were planted per plot. The design consisted of a RCB with four treatments $\left(2.77,5.53,8.30,11.06\right.$ plants $\left.\mathrm{m}^{-2}\right)$ and four replications. Lint yield $\left(\mathrm{kg} \mathrm{ha}^{-1}\right)$ was maximized at 6.54 plants $\mathrm{m}^{-2}$, while boll weight $\left(\mathrm{g}\right.$ boll ${ }^{-1}$ ) at less than 0 plants $\mathrm{m}^{-2}$. The second study involved planting cotton 
either in the conventional rows $\left(101.6 \mathrm{~cm}\right.$ apart, 4 rows bed $\left.{ }^{-1}\right)$ or in twin rows $(50.8 \mathrm{~cm}$ apart, 8 rows bed ${ }^{1}$ ), and spacing seed at a rate of 2 or 4 plants foot ${ }^{-1}$. Lint yield $\left(\mathrm{kg} \mathrm{ha}^{-1}\right)$ was minimized at 24.57 plants $\mathrm{m}^{-2}$, while boll weight $\left(\mathrm{g}\right.$ boll ${ }^{-1}$ ) at 41,40 plants $\mathrm{m}^{-2}$.

Wilson et al. (2002) presented the distribution of fruit (cotton boll) on five varieties with the genes for insect resistance $(B)$ and herbicide resistance (RR). Even mean boll weight was erratic in the first three nodes and on nodes 13 and greater, in between (nodes $4-12$ ) mean boll weight ranged between 4 and 5 grams boll depending on the variety. the greatest percentage of harvestable bolls occurred on nodes 9.13 which is where the greatest contribution to seedcotion yield occurred.

\section{Methods and Materials}

\subsection{Experimental Design and Field Work}

Seeding rate studies were conducted at the Coastal Plain Experiment Station (UGA-Titon Campus) in Tifton, Georgia, USA (Bednarz et al, 2000). Cotton ('Suregrow 501') was phnted April 25, 1997 at the main campus center pivot, May 9, 1997 at the Ponder Farm ( 9 miles west), and May 4, 1998 at the Ponder Farm. Five seeding rate treatments were established in a RCB with three replications at the center pivot using a Monosem air planter and consisted of 0.8104 .4 seeds foot ${ }^{-1}$ of row on $36^{\text {" }}$ rows (see Table 1). Four seeding rate treatments were established in a RCB with thee replications at the Ponder Farm using a Monosem air planter and consisted of 0.7106 .4 seeds foot ${ }^{-1}$ of row on $36^{\text {"f }}$ rows (see Table 2). Five seeding rate treatments were established in a RCB with four replications at the Ponder Farm using a Monosem air planter and consisted of 0.8105 .1 seeds foot of row on 36 " rows (see Table 3 ). Management practices at both locations were consistent with those of high yielding production systems. All locations were irrigated when soil moisture potentiometers indicated need. Upon crop maturity, 10 row feet $(3.048 \mathrm{~m})$ from each plot were box picked (all plants are cut off at $2^{\prime \prime}$ above ground and placed in a bag labeled with plot id for later examination) for yield distribution determination. Later, each plant in each bag was examined for location of each boll where its node number and position number on node were recorded as was the weight of the boll (Jenkins et al., 1990, Bednarz and Roberts, 2000, 2001: Bednarz, 2002). From the recorded data, the following data variables were available: Seedcotion yield (kg $\mathrm{ha}^{-1}$ ) for each node and position and total for the node, accumulated seedcoton yield ( $\left.\mathrm{kg} \mathrm{ha}^{-1}\right)$, percent harvestable bolls, and mean boll weight $\left(\mathrm{g} \mathrm{bol} \mathrm{H}^{-1}\right)$. Mean boll weight will be the only variable reported. The number of plants in each bag was also recorded. Density (plants $\mathrm{m}^{-2}$ ) was calculated from the number of plants in the bag.

Due to variableness of individual cotton plants that were sampled from each plot, higher nodes (branches) with few bolls were added to the next lower branch in the same fruiting position so that the highest node number was somewhat consistent within a treatment. Some outer positions (i.e., position three bolls) when found to be sparsely represented were added to position two data on the same node.

\subsection{Statistical Analysis of Data}

All data were analyzed using Proc MXED (Littell et al., 1996; SAS, 2000). The full model included as fixed effects: Density Treatment, Node, and Density $x$ Node interaction; while the random effects included: Replication (Rep), Rep x Density (Error a), Rep x Node (Error b), and Rep x Density x Node (Error c, called residual error in Proc MIXED).

The response surface model included as fixed effects: Density linear and quadratic, node linear, 
quadratic, and cubic, and density linear interacting with node linear and quadratic. Population density was centered on 9.836 (see Draper and Smith, 1981) using observed density - mean density (D - Dbar). Node was centered on 7 which is believed to be the peak producing node (Kerby, 1996; Jenkins et al., 1990) using observed node - peak node (N - peak N). Random effects include Error a, Error b, and Error c. Replication does not appear since it is confounded with individual plots. Each plot had its own population density due to planter and/or germination problems.

\section{Results and Discussion}

Preliminary analyses revealed that the three locations could not be analyzed together, especially for seedcotion yield $\left(\mathrm{kg} \mathrm{ha}^{-1}\right)$ and accumulated seedcoton yield $\left(\mathrm{kg} \mathrm{ha}^{-1}\right)$. The three fields are presented separately using the following notation: P97 = Ponder Farm 1997, R97 = RDC Center Pivot at main campus 1997, and P98 = Ponder Farm 1998. Unless otherwise noted the data are also presented as total of all positions (sum of positions 1-3), position one (bolls found at the first fruiting position on a fruting node [branch]), position two (bolls found at the second fruiting position on a node), and position three (bolls found at the remaining fruiting positions on a node). Summary of the data by field, density treatment, and fruiting node position is presented in Table 4. Note that the number of nodes with at least one cotton boll found was fairly consistent for positions one and two regardless of the population density. This is in contrast to the severe reduction experienced with position three boll production. At the highest density in P97-7, there were very few bolls found and these were incorporated into position two data resulting in the absence of any bolls which is believed to exist under nomal field conditions. The $\mathrm{N}$ presented are numbers of producing nodes found among the replications. The only variable presented reflecting individual plants is mean boll weight.

\subsection{Mean Boll Weight}

The full model analysis results for mean boll weight are shown in Tables 5, 7, \& 9 . The bolls found in each bag were weighed, counted, and mean boll weight was calculated. The value was recalculated when it was determined that extremely sparse boll data should be merged with neighboring data. The only places where harvestable bolls were found constitutes this data, position three is especially vulnerable to problems with sparse data. The response surface analyses are shown in Tables $6,8,8.10$. Regression coeficients from the response surface analyses are shown in Table 11.

Analysis results (full model) for mean boll weight from 997 appear in Table 5. Evident is the effect of population density being greater for every position data parameter compared with node. Both were significant for every parameter except for position three. Interaction between density and node was not significant for every position parameter, but position three had the largest effect. Random effect of error $\mathrm{c}$ was largest for positions one and two, somewhat smaller for total of all positions, and smaller yet for position three. Error $b$ random effect was positive for all four position data parameters with larger values for positions two and three. Error a random effect was positive for every position data parameter except for position three which fell victim due to sparseness of the data.

Analysis results (response surface) from 997 for mean boll weight appear in Table 6. Node quadratic and node linear were the largest significant fixed effects for total of all positions followed by density linear, density linear by node linear, and density linear by node quadratic, while node cubic was excluded $(\mathrm{F}<1)$. Node quadratic and node linear were the largest significant effects for position one followed by density linear, density linear by node quadratic, density linear by node linear, and density quadratic, while node cubic was excluded $(\mathrm{F}<1)$. Density linear was the largest significant effect for position two followed by node linear and node quadratic, while both interactions were excluded $(\mathrm{F}<1)$. 
Node linear was the only significant effect for position three even though node quadratic was nearly as large, but node cubic and both interactions were excluded $(F<1)$. Random effects for errors $a, b$, and $c$ were positive for total of all positions, and positions one and two. Random effects for errors a and c were positive and the only effects estimable for position three $(\mathrm{N}=43)$.

Analysis results (full model) for mean boll weight from R97 appear in Table 7. The erratic relationship between the effects of population density and node is evident. For total of all positions, although both $F$-values were similar only node was significant due primarily to error degrees of freedom. For position one, density was larger but both were significant. For position two, both were small resulting in node being significant and density was not. For position three, density was significant while node was extremely small and not significant. Interaction between density and node was significant for only position three. The random effect for error $c$ was largest for positions one and two. Error $b$ random effect was positive for all four position data parameters. Error a random effect was positive every position parameter except for position three (least data).

Analysis results (response surface) from $\mathrm{R} 97$ for mean boll weight appear in Table 8 . Node quadratic and node linear were the only significant fixed effects for total of all positions, while node cubic was excluded from the model $(\mathrm{F}<1)$. Node quadratic, density linear, node linear, and density quadratic were the only significant effects for position one, while all other effects were excluded $(\mathrm{F}<1)$. Node quadratic was the only significant effect for position two while density quadratic, node cubic, and both interactions were excluded $(F<1)$. Density linear and density linear by node linear were the only significant effects, while node quadratic and cubic, and the second interaction were excluded $(\mathrm{F}<\mathrm{l})$. Random effects for errors $a, b$, and $c$ were positive for total of all positions, and positions one and two. Random effect for error $\mathrm{c}$ was positive for position three $(\mathrm{N}=105)$.

Analysis results (full model) for mean boll weight from 198 appear in Table 9 . Node effect was significant for total of all positions, and positions one and two. Population density effect was significant only for position two where it was greater than the node effect. Interaction between density and node was significant for all position data parameters except for position two. The random effect of error cincreased from total of all positions through position three. Error b random effect was positive only for total of all positions and position three. Error a random effect was positive only for positions two and three.

Analysis results (response surface) from $\mathrm{P} 98$ for mean boll weight appear in Table 10. Node linear and quadratic, and both interactions were the only significant fixed effects for total of all positions and position two, while node cubic was excluded from the model $(F<1)$. Node linear and node quadratic were the only significant effects for position one, while density quadratic, node cubic, and density linear by node quadratic were excluded $(\mathrm{F}<1)$. Density linear and both interactions were the only significant effects for position three, while density quadratic and node cubic were excluded ( $\mathrm{F}<1$ ). Random effects for errors $a, b$, and $c$ were positive for positions two and three $(N=168)$. Random effects for errors $b$ and $c$ were positive for total of all positions, but only error $\mathrm{c}$ was positive for position one.

Figure 1 shows the graphical presentation of the effect of plant density and fruiting node on mean boll weight for P97. For total of all fruiting positions (Fig. 1a), mean boll weight increased towards fruiting nodes $10-11$ where it peaked and gradually declined with increasing node to 21 . There was a slight decline in mean boll weight as density increased towards 22.5 . For the first fruiting position (Fig. Ib), mean boll weight increased more sharply towards fruiting nodes $9-11$ where it peaked and declined sharply with increasing node to 21 . There was a distinct decline as density increased towards 14.5 where the decline became less. For the second fruiting position (Fig. 1c), mean boll weight increased sharply towards fruiting nodes $8-9$ where it peaked then declined more gradually to node 20 . Boll weight declined more until node 14.5 where the decline became less. For the third fruiting position (Fig. 10d), mean boll weight increased towards fruiting nodes 8.9 where it peaked then declined to node 18 . The decline in boll weight was sharp as density increased towards $9.5-11.5$ where there was a slight increase in boll weight 
towards 14.5. One notable feature was the regular decline in the number of nodes actually involved in producing bolls declining from $3-18$ to $6-13$.

Figure 2 shows the graphical presentation of the effect of plant density and fruiting node on mean boll weight for $\mathrm{R} 97$. The major difference between $\mathrm{P} 97$ and $\mathrm{R} 97$ was that the plant density reached only 15.5 for $R 97$, whereas it reached 22.5 for $P 97$. This one effect changed the relationship observed in the cotton that affected mean boll weight and where on the plant bolls were likely to be produced. For total of all positions (Fig. 2a), mean boll weight remained the same for the first 7 fruiting nodes (3-9) then began a gradual decline towards node 21 . This was fairly consistent over the range of plant densities. For the first fruiting position (Fig. 2b), the shape of the response surface was nearly the same as for the total of all positions. For the second fruiting position (Fig. 2c), the shape of the response surface suggests a gradual decline in mean boll weight from node 3 through 20 . For the third fruiting position (Fig. $11 \mathrm{~d}$ ), mean boll weight declined in all directions from node 3 at a density of 3.5 towards the higher nodes and/or densities.

Figure 3 shows the graphical presentation of the effect of plant density and fruiting node on mean boll weight for P98. A difference between $\mathrm{R} 97$ and P98 even though their plant densities did not exceed 15.5 and 18 respectively was the crop of cotton was more distributed across the nodes and positions in P98 than in R97 even though total yield was higher for R97. For total of all positions and the first position (Figs. $3 a, b$ ), the shape of the response surface compared with $R 97$ showed a slight increase in boll weight towards node 10 with P98. For the second position (Fig. 3c), the response surface has a distinct arch to it at the lower densities and a twisting trending towards the highest density and node 3 . For the third position (Fig. 3d), there was a definite decline in boll weights as the nodes increased even at the lower densities. But as density increased, the higher nodes became less involved then quit producing bolls unti only nodes $3-11$ were producing bolls.

\section{Summary}

Given that the literature tended to support the notion that fruiting node seven tended to be the greatest in terms of yield production on the cotton plant, it was discovered that actually nodes $7-12$ is the region of greatest impact on yield. Some evidence suggested that this region increased to $7-14$ or $8-14$ when moderate crowding occurred, but the region $7-12$ returned to be greatest when crowding became excessive. Definitely, position three quickly gave up production capabilities when crowding began to be excessive and eventually was excluded for all practical intent at densities exceeding 18 plants $\mathrm{m}^{-2}$. Position two picked up the slack until crowding became so excessive that it too gave up production capability. At the highest densities, it was position one that actually made the crop yield occur. The fact that mean boll weight remained above five grams boll ${ }^{-1}$ and percent harvestable bolls (data not shown) declined so sharply played a major role in total yield remaining high despite the fact that plant densities were reaching beyond the excessive level.

\section{Acknowledgments}

The authors would like to thank T. Dudley Cook (Field work), Lola Sexton (Lab work), several work study students from Abraham Baldwin Agricultural College, Cotton Incorporated, Cotton Foundation, Georgia Agricultural Commodity Commission for Cotton, and numerous corporate sponsors and supporters of cotton research at Coastal Plain Experiment Station, and the Assistant Director's office for funds to present the results of the statistical analysis at the Kansas State University's Conference on Applied Statistics in Agriculture, and finally the anonymous reviewers whose comments on the manuscript were invaluable. 


\section{References}

Baker, S. H. 1976. Response of cotton to row patterns and plant populations. Agronomy Joumal $68: 85-88$

Bednarz, C. W. 2002. Deternining cotton variety maturity classification and its effect on adaptation to the southeastem Coastal Plain. Cotton Research-Extension Revort 2001 , UGA/CPES Research-Extension Pub. 4, April 2002. pp 141-149.

Bednar, C. W. S. M. Brown, D. C. Bridges, S. H. Baker, 1998. Growth and development of cotton grown under several population densities. Cotton Research-Extension Report 1997 , UGA/CPES Research-Extension Pub. 4, March 1998. pp 200-216.

Bednar, C. W., D. C. Bridges, S. M. Brown. 2000. Analysis of cotton yield stablity across population densities. Agronomy Joumal $92: 128-135$.

Bednar, C. W., P. M. Roberts. 2000. Compensatory int yield production after arly season floral bud removal in cotton. Cotton Research-Extension Report 1999, UGA CPES ResearchExtension Pub. 4, March 2000. pp 128-134.

Bednar, C. W., P. M. Roberts. 2001. Spatial yield distribution in cotton following early-season floral bud removal. Crop Science 1:1800-1808.

Bridge, R. R., W. R. Meredith, J. F. Chism. 1973. Influence of planting method and plant population on cotton (Gossypium hirsutum L.). Agronomy Joumal 65:104-109.

Brown, S. M. 2002. The 2001 [cotton] crop in Georgia. Cotton Research-Extension Report 2001. UGA/CPES Research-Extension Pub. 4, April 2002. pp 1-2.

Culp, T. W., D. C. Harrell, J. B. Pitner. 1974. Population studies with cotton (Gossypim hirsumm L.). South Carolina Agric. Exp. Stn. Bull. 575. pp 1-11.

Draper, N. R., H. Smith. 1981. Applied regression analysis $\left(2^{\text {ra }}\right.$ Ed). New York: Wiley. 709 p.

Fowler, J. L., L. Ray. 1977. Response of two cotton genotypes to five equidistant spacing patterns. Agronomy Joumal 69:733-738.

Hawkins, B. S., H. A. Peacock. 1970. Yield response of upland coton (Gossypiam hirsum L.) to several spacing arrangements. Agronomv Joumal 62:578-580.

Hawkins, B. S. H. A. Peacock. 1973. Influence of row width and population density on yield and fber characteristics of cotton. Acronomy Joumal 69:733-738.

Hicks, S. K., C. W. Wendt, J. R. Gannaway, R. B. Baker. 1989. Allelopathic efects of wheat straw on cotton gemination, emergence, and yield. Crop Science 29:105\% 1061.

Jenkins, J. N., J. C. McCarty, Jr, W. L. Parrott. 1990. Effectiveness of fruiting sites in cotton yield. Crop Science 30:365-369.

Jones, M. A., R. Wells. 1997. Dry matter allocation and fruiting patterns of cotton grown at two divergent plant populations. Crop Science 37:797-802.

Littell, R. C., G. A. Milliken, W. W. Stroup, R. D. Wolfinger. 1996. SAS ${ }^{\text {TM }}$ Systen for Mixed Models. Cary, NC: SAS Institute Inc. 633 pp.

Kerby, T. A. 1996. Management considerations in cotton production with special emphasis on growing NuCOTN varieties with the Bollgard gene. Delta and Pine Land Co. Scot, MS. pp 1.49 . 
Kerby, T. A., K. G. Cassman, M. Keeley. 1990. Genotypes and plant densities for narrow-row cotton systems: 1. Height, nodes, earliness, and location of yield. Crop Science 31:644649.

SAS Institute Inc. 2000. SAS/C OnlineDoc ${ }^{\mathrm{TM}}$, Release 8.00 . Cary, NC: SAS Institute Inc. Smith, C. W., B. A. Waddle, H. H. Ramey, Jr. 1979. Plant spacings with irrigated cotton. Agronomy Joumal 71:858-860.

Wilson, G., W. Duffe, C. Bednarz. 2002. Evaluation of fruit distribution in stacked coton varieties across multiple locations. Cotton Research-Extension Report 2001, UGA/CPES Research-Extension Pub. 4, April 2001. pp 100-104. 
Table 1. Actual Plant Density and Range of Nodes by Plant and Position for Each Field Mlot from the Ponder Farm 9 miles West of Tifton, GA in 1997.

\begin{tabular}{|c|c|c|c|c|c|c|c|c|c|}
\hline \multirow{2}{*}{$\begin{array}{l}\text { Density } \\
\left(\text { no } n^{-2}\right)\end{array}$} & \multirow{2}{*}{ Rep } & \multicolumn{2}{|c|}{ All Positions } & \multicolumn{2}{|c|}{ First Position } & \multicolumn{2}{|c|}{ Second Position } & \multicolumn{2}{|c|}{ Third Position } \\
\hline & & Bottom & Top & Bottom & Top & Bottom & Top & Bottom & Top \\
\hline 2.51 & 1 & 3 & 21 & 3 & 21 & 3 & 18 & 3 & 18 \\
\hline 2.87 & 2 & 3 & 21 & 3 & 21 & 3 & 20 & 3 & 17 \\
\hline 3.95 & 3 & 3 & 20 & 3 & 20 & 3 & 17 & 3 & 15 \\
\hline 3.11 & Mean & 3 & 20 & 3 & 20 & 3 & 18 & 3 & 16 \\
\hline 10.04 & 1 & 3 & 21 & 3 & 21 & 3 & 19 & 4 & 9 \\
\hline 11.12 & 2 & 3 & 19 & 3 & 19 & 3 & 16 & 4 & 13 \\
\hline 10.40 & 3 & 3 & 19 & 3 & 19 & 3 & 18 & 5 & 9 \\
\hline 10.52 & Mean & 3 & 20 & 3 & 20 & 3 & 17 & 5 & 10 \\
\hline 13.27 & 1 & 3 & 20 & 3 & 20 & 4 & 16 & 6 & 13 \\
\hline 12.19 & 2 & 4 & 20 & 4 & 20 & 4 & 16 & 8 & 12 \\
\hline 12.91 & 3 & 3 & 18 & 3 & 18 & 3 & 14 & 6 & 10 \\
\hline 12.79 & Mcan & 3 & 19 & 3 & 19 & 4 & 15 & 6 & 11 \\
\hline 20.80 & 1 & 3 & 20 & 3 & 20 & 5 & 16 & $=$ & $=$ \\
\hline 21.88 & 2 & 4 & 19 & 4 & 19 & 6 & 15 & - & - \\
\hline 22.95 & 3 & 3 & 16 & 3 & 16 & 5 & 16 & - & . \\
\hline 21.88 & Mcan & 3 & 18 & 3 & 18 & 6 & 15 & - & - \\
\hline Mean & & 3 & 19 & 3 & 19 & 4 & 16 & 4 & 12 \\
\hline
\end{tabular}


Table 2. Actual Plant Density and Range of Nodes by Plant and Position for Each Field Plot from the Center Pivot on the CPES Tifton Campus, GA in 1997.

\begin{tabular}{|c|c|c|c|c|c|c|c|c|c|}
\hline \multirow{2}{*}{$\begin{array}{l}\text { Density } \\
\left(\text { no } \mathrm{m}^{-2}\right)\end{array}$} & \multirow{2}{*}{ Rep } & \multicolumn{2}{|c|}{ All Positions } & \multicolumn{2}{|c|}{ First Position } & \multicolumn{2}{|c|}{ Second Position } & \multicolumn{2}{|c|}{ Third Position } \\
\hline & & Bottom & Top & Bottom & Top & Bottom & Top & Bottom & Top \\
\hline 5.02 & 1 & 3 & 20 & 3 & 20 & 3 & 19 & 3 & 16 \\
\hline 2.87 & 2 & 3 & 21 & 3 & 21 & 3 & 20 & 3 & 14 \\
\hline 3.23 & 3 & 3 & 21 & 3 & 21 & 3 & 18 & 4 & 16 \\
\hline 3.71 & Mean & 3 & 20 & 3 & 20 & 3 & 19 & 4 & 15 \\
\hline 5.02 & 1 & 3 & 21 & 3 & 21 & 3 & 20 & 3 & 14 \\
\hline 5.38 & 2 & 3 & 21 & 3 & 21 & 3 & 18 & 3 & 16 \\
\hline 5.38 & 3 & 3 & 21 & 3 & 21 & 3 & 20 & 3 & 17 \\
\hline 5.26 & Mean & 3 & 21 & 3 & 21 & 3 & 19 & 3 & 15 \\
\hline 8.97 & 1 & 3 & 21 & 3 & 21 & 3 & 18 & 4 & 17 \\
\hline 9.32 & 2 & 3 & 21 & 3 & 21 & 3 & 18 & 3 & 16 \\
\hline 12.55 & 3 & 3 & 20 & 3 & 20 & 3 & 19 & 5 & 18 \\
\hline 10.28 & Mean & 3 & 20 & 3 & 20 & 3 & 18 & 4 & 17 \\
\hline 13.63 & 1 & 3 & 21 & 3 & 21 & 3 & 19 & 6 & 17 \\
\hline 12.91 & 2 & 3 & 19 & 3 & 19 & 3 & 15 & 5 & 12 \\
\hline 11.84 & 3 & 3 & 21 & 3 & 21 & 3 & 21 & 3 & 19 \\
\hline 12.79 & Mean & 3 & 20 & 3 & 20 & 3 & 18 & 4 & 16 \\
\hline 13.99 & 1 & 3 & 20 & 3 & 20 & 3 & 20 & 6 & 14 \\
\hline 15.78 & 2 & 3 & 19 & 3 & 19 & 3 & 16 & 6 & 14 \\
\hline 15.78 & 3 & 3 & 20 & 3 & 20 & 3 & 19 & 7 & 15 \\
\hline 15.18 & Mean & 3 & 19 & 3 & 19 & 3 & 18 & 7 & 14 \\
\hline Mean & & 3 & 20 & 3 & 20 & 3 & 18 & 5 & 16 \\
\hline
\end{tabular}


Table 3. Actual Plant Density and Range of Nodes by Plant and Position for Each Field Plot from the Ponder Farm 9 miles West of Tifton, GA in 1998.

\begin{tabular}{|c|c|c|c|c|c|c|c|c|c|}
\hline \multirow{2}{*}{$\begin{array}{l}\text { Density } \\
\left(\text { no } \mathrm{m}^{-2}\right)\end{array}$} & \multirow{2}{*}{ Rep } & \multicolumn{2}{|c|}{ All Positions } & \multicolumn{2}{|c|}{ First Position } & \multicolumn{2}{|c|}{ Second Position } & \multicolumn{2}{|c|}{ Third Position } \\
\hline & & Bottom & Top & Bottom & Top & Bottom & Top & Bottom & Top \\
\hline 3.23 & 1 & 3 & 19 & 3 & 19 & 3 & 19 & 3 & 16 \\
\hline 2.87 & 2 & 3 & 20 & 3 & 20 & 3 & 17 & 3 & 14 \\
\hline 3.59 & 3 & 3 & 21 & 3 & 21 & 3 & 19 & 3 & 17 \\
\hline 2.87 & 4 & 3 & 20 & 3 & 20 & 3 & 18 & 3 & 18 \\
\hline 3.14 & Mean & 3 & 20 & 3 & 20 & 3 & 18 & 3 & 16 \\
\hline 5.68 & 1 & 3 & 21 & 3 & 21 & 3 & 18 & 3 & 17 \\
\hline 5.02 & 2 & 3 & 21 & 3 & 21 & 3 & 19 & 3 & 17 \\
\hline 6.10 & 3 & 3 & 19 & 3 & 19 & 3 & 16 & 3 & 15 \\
\hline 6.10 & 4 & 3 & 17 & 3 & 17 & 3 & 17 & 3 & 15 \\
\hline 5.65 & Mean & 3 & 19 & 3 & 10 & 3 & 17 & 3 & 16 \\
\hline 7.89 & 1 & 3 & 19 & 3 & 19 & 3 & 16 & 3 & 14 \\
\hline 7.89 & 2 & 3 & 17 & 3 & 17 & 3 & 15 & 3 & 14 \\
\hline 7.89 & 3 & 3 & 19 & 3 & 19 & 4 & 17 & 3 & 15 \\
\hline 8.97 & 4 & 3 & 18 & 3 & 18 & 3 & 16 & 3 & 16 \\
\hline 8.16 & Mean & 3 & 18 & 3 & 18 & 4 & 16 & 3 & 14 \\
\hline 11.48 & 1 & 3 & 18 & 3 & 18 & 3 & 18 & 3 & 16 \\
\hline 10.04 & 2 & 3 & 19 & 3 & 19 & 3 & 15 & 3 & 14 \\
\hline 10.76 & 3 & 3 & 19 & 3 & 19 & 3 & 16 & 3 & 13 \\
\hline 10.40 & 4 & 3 & 17 & 3 & 17 & 3 & 15 & 3 & 14 \\
\hline 10.67 & Mean & 3 & 18 & 3 & 18 & 3 & 16 & 3 & 14 \\
\hline 15.06 & 1 & 3 & 18 & 3 & 18 & 3 & 16 & 3 & 14 \\
\hline 18.29 & 2 & 3 & 17 & 3 & 17 & 3 & 17 & 3 & 17 \\
\hline 14.35 & 3 & 3 & 19 & 3 & 19 & 3 & 14 & 3 & 10 \\
\hline 17.57 & 4 & 3 & 17 & 3 & 17 & 3 & 15 & 3 & 11 \\
\hline 16.32 & Mean & 3 & 17 & 3 & 17 & 3 & 15 & 3 & 13 \\
\hline Mean & & 3 & 18 & 3 & 18 & 3 & 16 & 3 & 15 \\
\hline
\end{tabular}


Table 4. Mean planting density, and number nodes and node range by treatment for three fields for each of three node positions for 1997 and 1998 in Tifton.

\begin{tabular}{|c|c|c|c|c|c|c|c|}
\hline \multirow{2}{*}{$\begin{array}{l}\text { Field- } \\
\text { Treatment }\end{array}$} & \multirow{2}{*}{$\begin{array}{l}\text { Population } \\
\text { Density } \\
\left(\text { no } \mathrm{m}^{-2}\right)\end{array}$} & \multicolumn{2}{|c|}{ Position One } & \multicolumn{2}{|c|}{ Position Two } & \multicolumn{2}{|c|}{ Position Three } \\
\hline & & $\mathrm{N}$ & Node Range & $\mathrm{N}$ & Node Range & $N$ & Node Range \\
\hline $\mathrm{PQT}^{-1^{3}}$ & $3.11(0.62)$ & 56 & $3-21$ & 49 & $3-20$ & 44 & 3.18 \\
\hline $\mathrm{P9} 9-3$ & $10.52(0.48)$ & 53 & $3-21$ & 47 & $3-19$ & 21 & $4 \cdot 13$ \\
\hline p97.4 & $12.79(0.47)$ & 51 & $3-20$ & 38 & $3 \cdot 16$ & 18 & $6-13$ \\
\hline p97.7 & $21.88(0.90)$ & 48 & $3-20$ & 34 & $5-16$ & 0 & $\cdots$ \\
\hline $\mathrm{R} 97.1$ & $3.71(0.95)$ & 56 & $3-21$ & 48 & $3-19$ & 40 & $3-16$ \\
\hline $\mathrm{R} 97.2$ & $5.26(0.20)$ & 57 & 3.21 & 52 & $3-20$ & 41 & $3-17$ \\
\hline$R 97-3$ & $10.28(1.62)$ & 56 & $3-21$ & 49 & $3-19$ & 42 & $3-18$ \\
\hline $\mathrm{R} 97-4$ & $12.79(0.78)$ & 55 & $3-21$ & 49 & $3-21$ & 37 & $3-19$ \\
\hline $\mathrm{R} 97.5$ & $15.18(0.87)$ & 53 & $3-20$ & 48 & 3.20 & 27 & $6-15$ \\
\hline P98.1 & $3.14(0.31)$ & 72 & 3.21 & 65 & $3-19$ & 57 & $3-18$ \\
\hline p98-2 & $5.65(0.47)$ & 70 & $3-21$ & 62 & 3.19 & 56 & $3-17$ \\
\hline 098.3 & $8.16(0.48)$ & 65 & $3-19$ & 55 & $3-17$ & 51 & $3-16$ \\
\hline P98-4 & $10.67(0.56)$ & 65 & 3.19 & 56 & $3-18$ & 49 & $3-16$ \\
\hline P98.6 & $16.32(1.68)$ & 62 & $3-18$ & 54 & 3.17 & 44 & 3.17 \\
\hline
\end{tabular}

Notes: 1: Position 3 would include any cotton bolls found further out on the node branch. Standard deviation enclosed in parentheses, mean and SD are weighted to the number of producing nodes found having a cotton boll in position 1. 3: P97 = Ponder $1997, \mathrm{R} 97=$ RDC Pivot 1997, and P98 = Ponder 1998. Treatments 1.7 represent number of cotton seeds planted per foot by settings on the Monosem air planter. Since the seed is small, two seeds being planted is not uncommon and hard to guard against. Plot thinning was done to try to achieve the desired population density for each plot. 
Table 5. F-tests (fixed) and variance components (random) from full mixed model applied to mean boll weight ( $\mathrm{g}$ boll ${ }^{-1}$ ) for all positions, position one, two, and three grown at Ponder Farm 1997 in Tift County. Georgia.

\begin{tabular}{|c|c|c|c|c|c|c|c|c|}
\hline \multirow{3}{*}{$\begin{array}{l}\text { Mixed } \\
\text { Model } \\
\text { Erects }\end{array}$} & \multicolumn{8}{|c|}{ 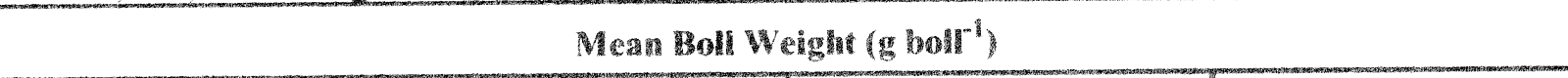 } \\
\hline & \multicolumn{2}{|c|}{ All Positions } & \multicolumn{2}{|c|}{ Position One } & \multicolumn{2}{|c|}{ Position Two } & \multicolumn{2}{|c|}{ Position Thres } \\
\hline & $d f$ & Value & df & Value & $d r$ & Value & dif & Value \\
\hline Random & \multicolumn{8}{|c|}{ Varonare Components } \\
\hline Replication & 2 & 0.0430 & 2 & 0.0454 & 2 & 0.0068 & 2 & 0 \\
\hline Error a & 6 & 0.0377 & 6 & 0.0410 & 6 & 0.0967 & 1 & 0 \\
\hline Error b & 29 & 0.1047 & 29 & 0.0551 & 22 & $0.3061+$ & 18 & 0.5738 \\
\hline Error $\mathbb{C}$ & 68 & $0.4710^{* *}$ & 68 & $0.6639 * *$ & 40 & $0.6758 * *$ & 1 & 0.3218 \\
\hline Fixed & \multicolumn{8}{|c|}{ Wests } \\
\hline Density & 3 & $10.66^{* * *}$ & 3 & $16.18^{2 *}$ & 3 & $8.56^{*}$ & 2 & 16.13 \\
\hline Node & 15 & $4.47 \cos ^{2}$ & 15 & $5.50^{* *}$ & 13 & $2.27 *$ & 11 & 0.95 \\
\hline Density x Node & 42 & 1.10 & 42 & 1.10 & 27 & 1.47 & 6 & 5.16 \\
\hline
\end{tabular}

Note: $t, * *$ denote significance levels of $P=0.10,0.05,0,01$, respectively, $\mathrm{N}=166,166,114,42$ for All Positions, Positions One, Two, and Three, respectively. 
Table 6. F-tests (fixed) and variance components (random) from response surface mixed model applied to mean boll weight boll $^{-1}$ ) for all positions, position one. two, and three grown at Ponder Farm 1997 in Tift County, Georgia.

\begin{tabular}{|c|c|c|c|c|c|c|c|c|}
\hline \multirow{3}{*}{$\begin{array}{l}\text { Mixed } \\
\text { Model } \\
\text { Erfocts }\end{array}$} & \multicolumn{8}{|c|}{ Mean Boll Veight $\left(\mathrm{g} \mathrm{boI}^{-1}\right)$} \\
\hline & \multicolumn{2}{|c|}{ All Positions } & \multicolumn{2}{|c|}{ Position One } & \multicolumn{2}{|c|}{ Position Two } & \multicolumn{2}{|c|}{ Position Three } \\
\hline & df & Value & df & Value & df & Value & df & Value \\
\hline Random & \multicolumn{8}{|c|}{ Variarace Components } \\
\hline Error a & 9 & $0.0707 *$ & 9 & $0.0590+$ & 9 & 0.0804 & 3 & $0.6732^{2}$ \\
\hline Error b & 42 & $0.1117 *$ & 42 & $0.1242^{*}$ & 32 & $0.4418+$ & 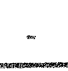 & - \\
\hline Error c & 108 & $0.4543 *$ & 108 & $0.6189 * *$ & 67 & $0.8045^{* * *}$ & 34 & $0.9040 * *$ \\
\hline Fixed & \multicolumn{8}{|c|}{ Wrests } \\
\hline Density Lincar & 1 & $6.86^{*}$ & 1 & $16.86 * *$ & 1 & $18.24 * *$ & 1 & 0.04 \\
\hline Density Quadratic & 1 & 2.08 & 1 & $6.30^{*}$ & 1 & 2.63 & 1 & 0.65 \\
\hline Node Linear & 1 & $39.39^{* * *}$ & 1 & $39.67 * *$ & 1 & $14.83 * *$ & 1 & $4.19 *$ \\
\hline Node Quadratic & 1 & 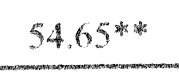 & 1 & $57.42 * *$ & 1 & $6.60^{*}$ & 1 & $4.00+$ \\
\hline Node Cubic & - & $\ldots$ & - & - & 1 & 1.55 & - & - \\
\hline Density L X Node L. & 1 & $6.17^{*}$ & 1 & 9.89 \% & $\sim$ & 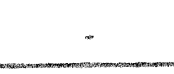 & $\sim$ & - \\
\hline Density L $\times$ Nodo Q & 1 & $5.32 *$ & 1 & $10.066^{2}$ & - & - & - & 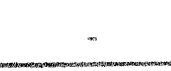 \\
\hline
\end{tabular}

Note: $+* * *$ denote significance levels of $-0.10,0.05,0.01$, respectively. $N=160,166,114,42$ for $\mathrm{All}$ Positions, Positions One,

Two, and Three, respectively. Replication not included as a random since it is confound with hiting density in model. 
Table 7. F-tests (fixed) and variance components (random) from full mixed model applied to mean boll weight (g boll ${ }^{-1}$ ) for all positions, position one, two, and three grown at Main Campus RDC Pivot 1997 in Tift County, Georgia.

\begin{tabular}{|c|c|c|c|c|c|c|c|c|}
\hline \multirow{3}{*}{$\begin{array}{l}\text { Mixed } \\
\text { Model } \\
\text { Effects }\end{array}$} & \multicolumn{8}{|c|}{ 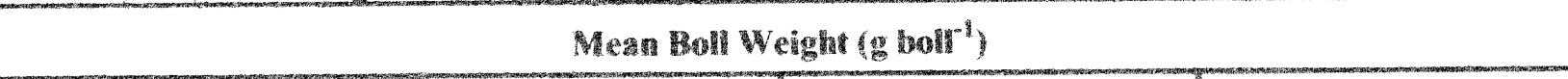 } \\
\hline & \multicolumn{2}{|c|}{ All Positions } & \multicolumn{2}{|c|}{ Position One } & \multicolumn{2}{|c|}{ Position Two } & \multicolumn{2}{|c|}{ Position Three } \\
\hline & $d f$ & Value & $d \hat{r}$ & Value & di & Vahe & $d f$ & Value \\
\hline Randon & \multicolumn{8}{|c|}{ 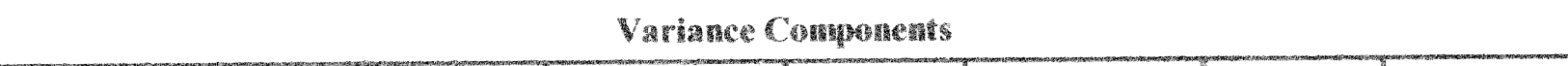 } \\
\hline Replication & 2 & 0.0121 & 2 & 0.0119 & 2 & 0 & 2 & 0.0071 \\
\hline Error a & 8 & 0.0327 & 8 & 0.0115 & $x$ & $0.1473+$ & 8 & 0 \\
\hline Error b & 32 & 0.0084 & 31 & 0.0624 & 26 & 0.0332 & 20 & 0.1799 \\
\hline Error & 112 & $0.4488 *$ * & 111 & $0.6656^{\cdots}$ & 78 & $0.7509 *$ & 23 & $0.5630^{\text {糔 }}$ \\
\hline Fixed & \multicolumn{8}{|c|}{ 算 } \\
\hline Density & 4 & 2.73 & 4 & $6.08 *$ & 4 & 1.00 & 4 & $5.97 *$ \\
\hline Node & 17 & $2.76^{*} \cdot{ }^{2}$ & 17 & $2.49 *$ & 16 & $1.95 \%$ & 13 & 0.42 \\
\hline Density x Node & 65 & 0.87 & 65 & 0.93 & 54 & 1.23 & 34 & $2.13^{23}$ \\
\hline
\end{tabular}

Note: $+*$ * denote significance levels of $P=0.10,0.05,0.01$, respectively. $N=241,240,189,105$ for All Positions, Positions One, Two, and Three, respectively. 
Table 8. F-tests (fixed) and variance components (random) from response surface mixed model applied to mean boll weight boll ${ }^{-1}$ ) for all positions, position one, two, and three grown at Campus Pivot 1997 in Tift County, Georgia.

\begin{tabular}{|c|c|c|c|c|c|c|c|c|}
\hline \multirow{3}{*}{$\begin{array}{l}\text { Mixed } \\
\text { Model } \\
\text { Effects }\end{array}$} & \multicolumn{8}{|c|}{ Mean Boll Weight (g bon" ) } \\
\hline & \multicolumn{2}{|c|}{ All Positions } & \multicolumn{2}{|c|}{ Position One } & \multicolumn{2}{|c|}{ Position Two } & \multicolumn{2}{|c|}{ Position Three } \\
\hline & df & Value & df & Value & df & Value & df & Value \\
\hline Random & \multicolumn{8}{|c|}{ Variance Components } \\
\hline Errot a & 12 & $0.0223+$ & 12 & 0.0016 & 13 & $0.0877 *$ & 12 & 0 \\
\hline Error b & 47 & 0.0234 & 47 & 0.0482 & 40 & 0.0185 & 32 & 0 \\
\hline Error $\mathrm{c}$ & 175 & $0.4135^{* *}$ & 176 & $0.6427 \%$ & 132 & $0.8310^{* *}$ & 56 & $0.8363^{*}$ \\
\hline Fixed & \multicolumn{8}{|c|}{ Netests } \\
\hline Density Lincar & 1 & 1.96 & 1 & $14.96 * *$ & 1 & 2.16 & 1 & $15.80^{* * *}$ \\
\hline Density Quadratic & 1 & $4.27+$ & 1 & $4.84 *$ & - & - & 1 & 1.58 \\
\hline Node Lincar & 1 & $10.71 *$ & 1 & $7.67 * *$ & 1 & 0.37 & 1 & 0.09 \\
\hline Node Quadratic & 1 & $28.26 *$ & 1 & 25.67 * & 1 & $4.80^{*}$ & - & - \\
\hline Node Cubic & - & $\sim$ & - & - & - & - & 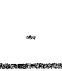 & 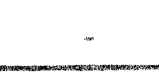 \\
\hline Density L x Node L & 1 & 2.02 & - & - & 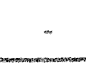 & - & 1 & $9.48 * *$ \\
\hline Density $L$ x Node Q & 1 & $3.36+$ & - & - & - & - & - & - \\
\hline
\end{tabular}

Note: $+* * *$ denote significance levels of $p=0.10,0.05,0.01$, respectively. $N=241,240,189,105$ for All Positions, Positions Onc,

Two, and Threc, respectively. Replication not included as a random since it is confound with fitting density in model. 
Table 9. Fuests (fixed) and variance components (random) from full mixed model applied to mean boll weight (g boll ${ }^{-1}$ ) for all positions, position one, two, and three grown at Ponder Farm 1998 in Tift County, Gcorgia.

\begin{tabular}{|c|c|c|c|c|c|c|c|c|}
\hline \multirow{3}{*}{$\begin{array}{l}\text { Mixed } \\
\text { Model } \\
\text { Efrects }\end{array}$} & \multicolumn{8}{|c|}{ Mcan Doul Weight (s boll') } \\
\hline & \multicolumn{2}{|c|}{ All Positions } & \multicolumn{2}{|c|}{ Position One } & \multicolumn{2}{|c|}{ Position Two } & \multicolumn{2}{|c|}{ Position Three } \\
\hline & $d f$ & Value & $d r$ & Value & $d f^{\circ}$ & Value & df & Value \\
\hline Randon & \multicolumn{8}{|c|}{ Variance Components } \\
\hline Replication & 3 & 0.0182 & 3 & 0.0014 & 3 & 0.0003 & 3 & 0.0110 \\
\hline Error a & 12 & 0 & 12 & 0 & 12 & 0.0109 & 12 & 0.0803 \\
\hline Error b & 42 & 0.0158 & 41 & 0 & 34 & 0 & 30 & 0.0115 \\
\hline Error $\mathrm{c}$ & 134 & $0.3796 * *$ & 129 & $0.6067 * *$ & 101 & $0.6807 * 3$ & 70 & $0.8628^{* * *}$ \\
\hline Fixed & \multicolumn{8}{|c|}{ Tests } \\
\hline Density & 4 & 2.06 & 4 & 2.33 & 4 & $4.47 *$ & 4 & 0.83 \\
\hline Node & 15 & $6.72 *$ & 15 & $5.67^{*}$ & 13 & $2.71 \%$ & 11 & 1.66 \\
\hline Density $x$ Node & 53 & $1.48 *$ & 53 & $1.53 \%$ & 44 & 1.37 & 37 & $1.61^{*}$ \\
\hline
\end{tabular}

Note: $+* * *$ denote significance levels of $P 0.10,0.05,0,01$, respectively $N=264,258,212$, 168 for All Positions, Positions One. Two, and Three, respectively. 
Table 10. F-tests (fixed) and variance components (random) from response surface mixed model applied to mean boll weight boll ${ }^{-1}$ for all positions, position one, two, and three grown at Ponder Farm 1998 in Tift County, Georgia.

\begin{tabular}{|c|c|c|c|c|c|c|c|c|}
\hline \multirow{3}{*}{$\begin{array}{l}\text { Mixed } \\
\text { Model } \\
\text { Efrects }\end{array}$} & \multicolumn{8}{|c|}{ Mean Moll Weight (s boll') } \\
\hline & \multicolumn{2}{|c|}{ All Positions } & \multicolumn{2}{|c|}{ Position One } & \multicolumn{2}{|c|}{ Position Two } & \multicolumn{2}{|c|}{ Position Three } \\
\hline & df & Value & df & Value & df & Value & $d f$ & Value \\
\hline Random & \multicolumn{8}{|c|}{ 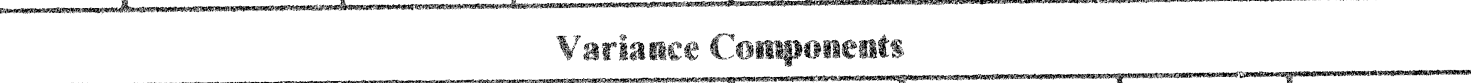 } \\
\hline Error a & 17 & 0 & 18 & 0 & 17 & 0.0385 & 18 & 0.0273 \\
\hline Error b & 55 & $0.0480+$ & 54 & 0 & 45 & 0.0434 & 39 & $0.1542+$ \\
\hline Error e & 185 & $0.3948^{* *}$ & 181 & $0.6923 \%$ * & 143 & $0.6628 *$ & 105 & $0.8613^{3}$ \\
\hline Fixed & \multicolumn{8}{|c|}{ E } \\
\hline Density Lincar & 1 & 0.20 & $\mathbb{1}$ & 1.22 & 1 & 1.88 & 1 & $11.02 *$ * \\
\hline Density Quadratic & 1 & 0.85 & - & - & 1 & 1.93 & - & 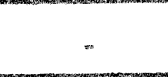 \\
\hline Node Lincar & 1 & $38.24 *$ & 1 & $24,38 * \cdots$ & 1 & $8.38^{4}$ & 1 & 0.44 \\
\hline Node Quadratic & 1 & $36.02^{* * 2 \times}$ & 1 & $47.86 * *$ & 1 & $5.95 *$ & 1 & 0.58 \\
\hline Node Cubic & - & - & $=$ & 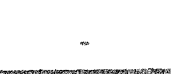 & $\cdots$ & - & - & 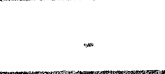 \\
\hline Density L $\mathrm{x}$ Node L & 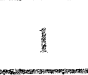 & $13.82 * *$ & 1 & 2.48 & 1 & $14.58 * *$ & 1 & $7.93 * *$ \\
\hline Density L $\times$ Node Q & 1 & $6.61^{* *}$ & - & - & 1 & $8.00 * *$ & 1 & $18.77 * * 2$ \\
\hline
\end{tabular}

Note:,$+ * *$ denote significance levels of $P=0.10,0.05,0.01$, respectively. $\mathrm{N}=264,258,212,168$ for All Positions, Positions Onc,

Two, and Threc, respectively. Replication not included as a random since it is confound with fitting density in model. 
Tabie 11. Regression coefficients for mean boll weight $\left(\mathrm{g}\right.$ boll ${ }^{-1}$ ) from fitting the response surface of plant density (quadratic) and fruiting nodes (cubic) with two interaction terms for the three fields and total fruiting position on a node, and first, second, and third fruiting positions.

\begin{tabular}{|c|c|c|c|c|}
\hline Regression Efrect & Total All Positions & First Position & Second Position & Third Position \\
\hline \multicolumn{5}{|c|}{ Ponder Farm 1997 } \\
\hline intercept & 4.3707 & 4.5301 & 3,9319 & 2.9300 \\
\hline Density Linear (DL) & -0.06609 & -0.1049 & -0.1064 & 0.05396 \\
\hline Density Quadratic & 0.003429 & 0.006050 & 0.004952 & 0.03880 \\
\hline Node Linear (NL) & 0.2560 & 0.2880 & 0.3157 & 0.1948 \\
\hline Node Quadratic (NQ) & .0 .03227 & 0.03709 & -0.07652 & -0.03369 \\
\hline Node Cubic &..- & $\cdots$ & 0.003414 & $\ldots$ \\
\hline$D L \times N$ & -0.01154 & -0.01705 & $\ldots$ & $\ldots$ \\
\hline $\mathrm{DL} \times \mathrm{NQ}$ & 0.001178 & 0.001890 & $\ldots$ & $\cdots$ \\
\hline \multicolumn{5}{|c|}{ CHES Main Compus Prot 1997} \\
\hline Intercept & 4.0437 & 4.3509 & 4.0295 & 2.9406 \\
\hline Density Lincar (DL) & -0.02804 & -0.05509 & -0.03384 & -0.1392 \\
\hline Density Quadratic & 0.009153 & 0.009472 & $\ldots$ & 0.008740 \\
\hline NodeLincar (NL) & 0.05814 & 0.07852 & 0.02202 & 0.01014 \\
\hline Nodc Quadratic (NQ) & -0.00551 & -0.01443 & -0.00986 & $\ldots$ \\
\hline Node Cubic & -0.00043 & $\ldots$ & $\cdots$ & $\cdots$ \\
\hline$D L \times N L$ & -0.00116 & $\cdots$ & $-\cdots$ & 0.02483 \\
\hline $\mathrm{DL} \times \mathrm{NQ}$ & $\ldots$ & $\ldots$ & $\ldots$ & $\ldots$ \\
\hline \multicolumn{5}{|c|}{ Pender Tarm 1998} \\
\hline Intercept & 4.2106 & 4.5973 & 4.0418 & 3.6367 \\
\hline Donsity Linear (DL) & 0.001997 & -0.01679 & .0 .03017 & -0.08831 \\
\hline Density Quadratic & -0.4312 & $\ldots$ & 0.004983 & $\cdots$ \\
\hline Node Linear (NL) & 0.1700 & 0.1513 & 0.1255 & 0.04079 \\
\hline Node Quadratic (NQ) & .0 .02227 & -0.02582 & -0.01814 & -0.00881 \\
\hline Node Cubic & $-\ldots$ & $\ldots$ & -n. & $\ldots$ \\
\hline$D L \times N L$ & -0.01718 & -0.00504 & -0.03203 & -0.02909 \\
\hline $\mathrm{DL} \times \mathrm{NQ}$ & 0.001604 & $\cdots$ & 0.003745 & 0.007824 \\
\hline
\end{tabular}


Figure 1. Effect of interaction between plant density and fruiting node on mean boll weight ( $\mathrm{g}$ boll ${ }^{-1}$ ) for total of all node fruiting positions, node fruiting position one, two and three at the Ponder Farm in 1997 in Tift County, Georgia.

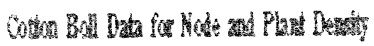

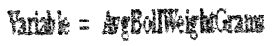

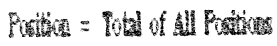 \\ Whe-Fudet
}

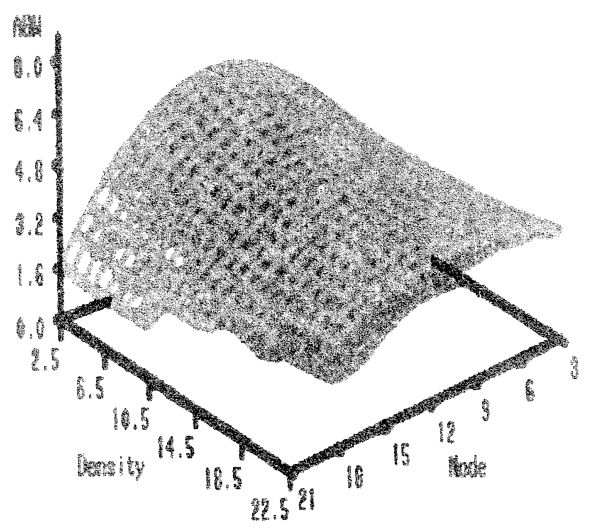

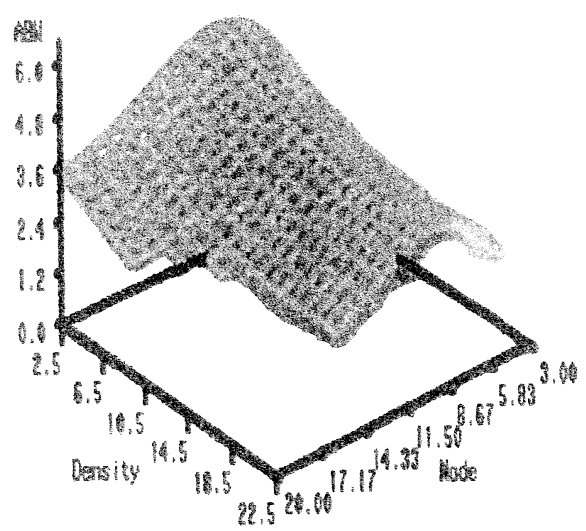

a

$\mathrm{b}$

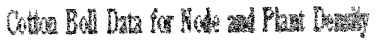

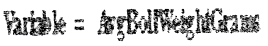

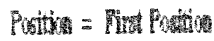

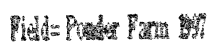

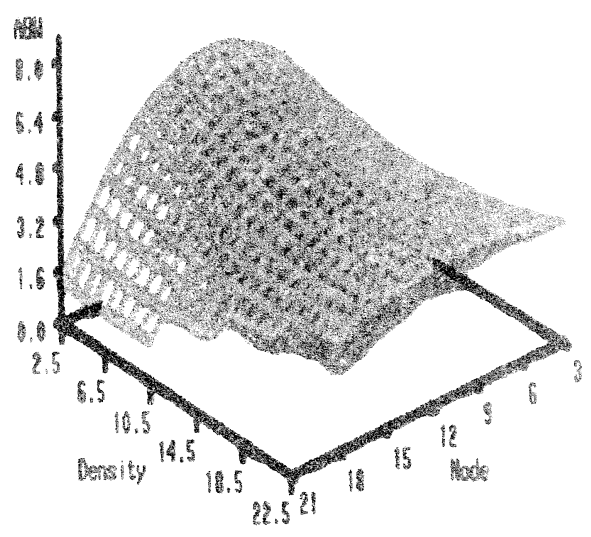

d

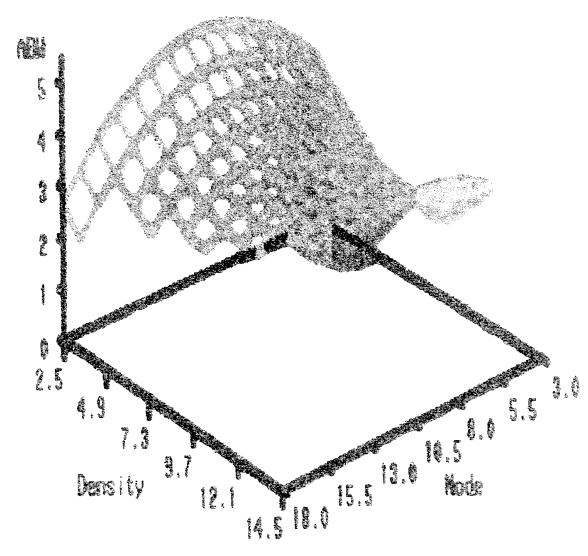


Figure 2. Effect of interaction between plant density and fruiting node on mean boll weight ( $\mathrm{g}$ boll ${ }^{-1}$ ) for total of all node fruiting positions, node fruiting position one, two and three at the CPES Main Campus Pivot in 1997 in Tif County, Georgia.

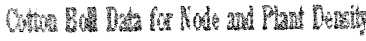

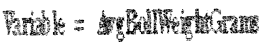

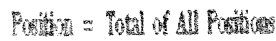 \\ Pul-ord row}

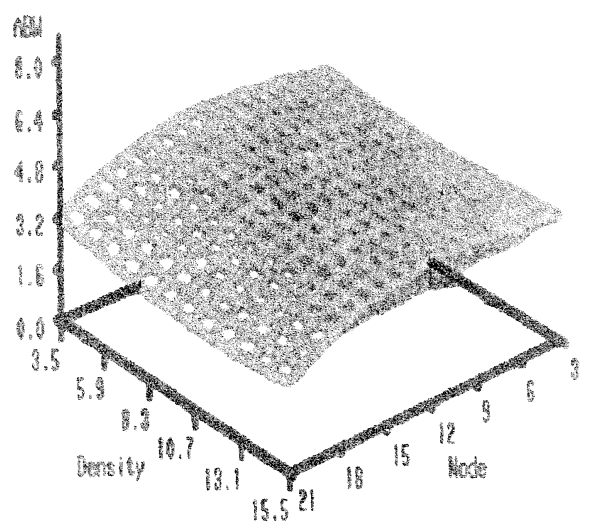

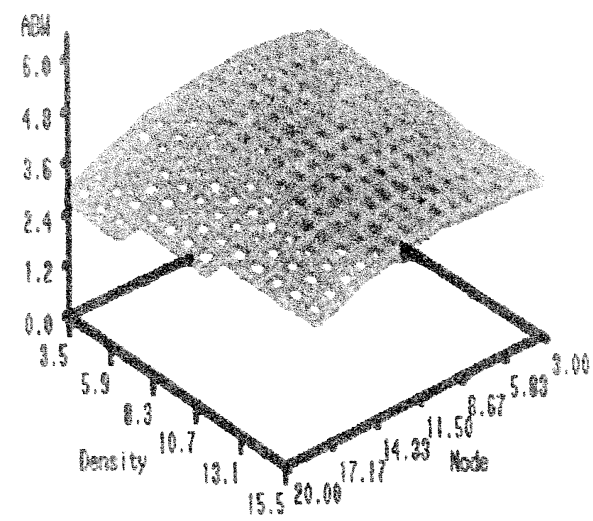

a b

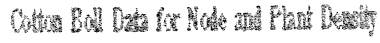

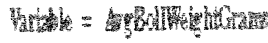

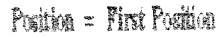

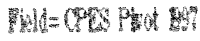

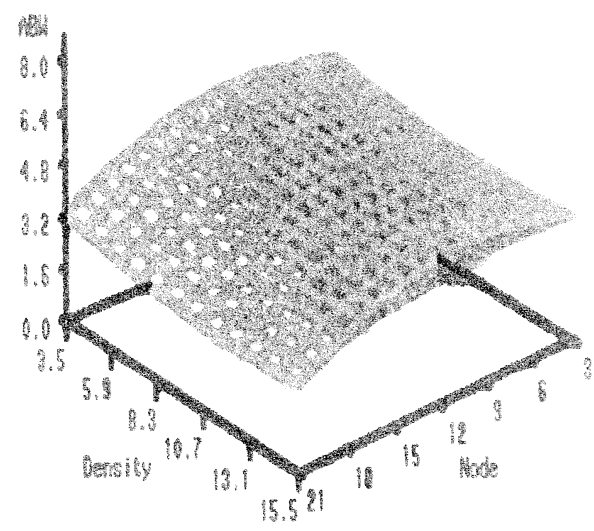

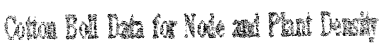

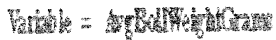

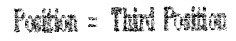

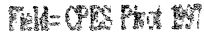

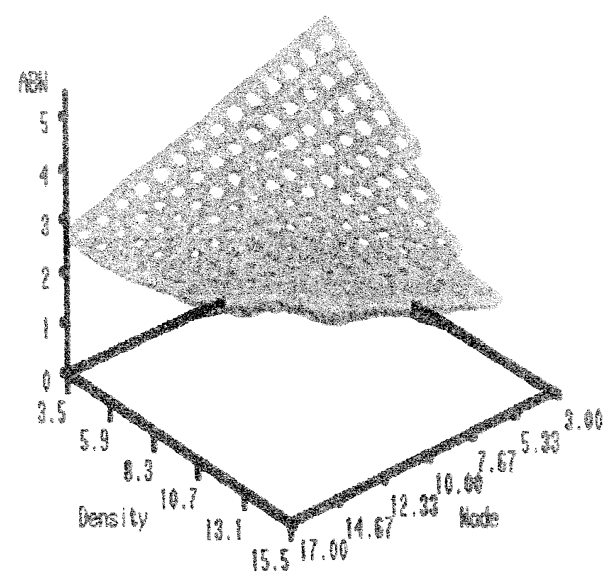


Figure 3. Effect of interaction between plant density and fruiting node on mean boll weight $\left(\mathrm{g}\right.$ boll $\left.{ }^{-1}\right)$ for total of all node fruting positions, node fruting position one, two and three at the Ponder Farm in 1998 in Tift County, Georgia.

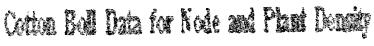

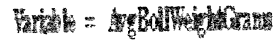

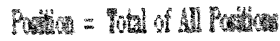

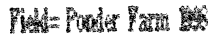

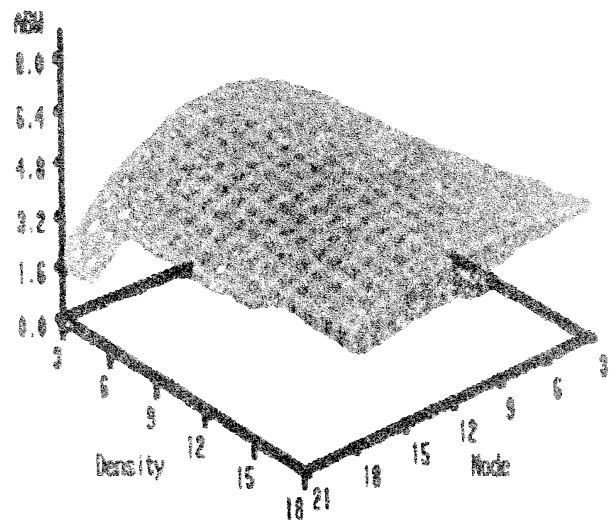

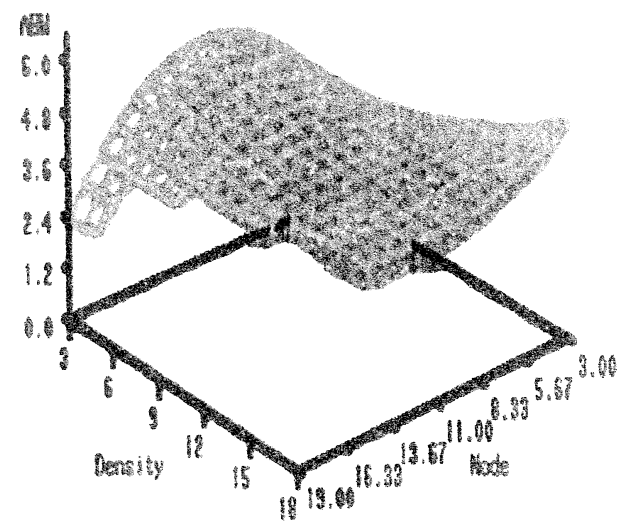

a

b

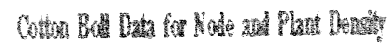

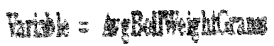

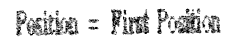

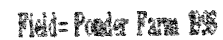

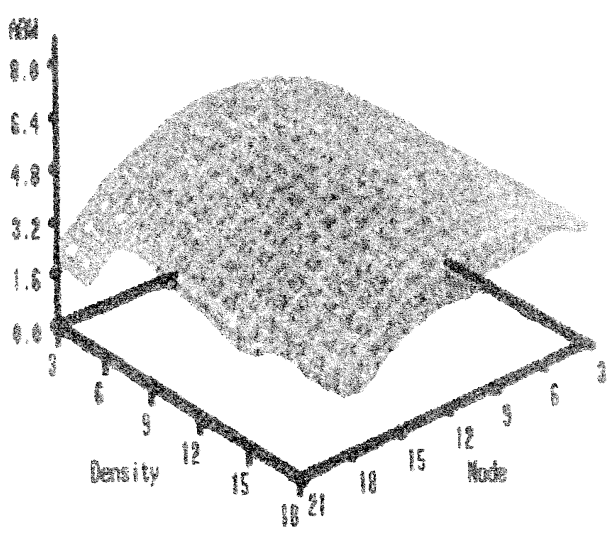

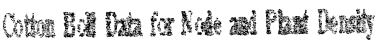

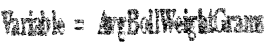

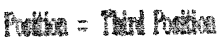

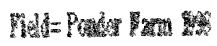

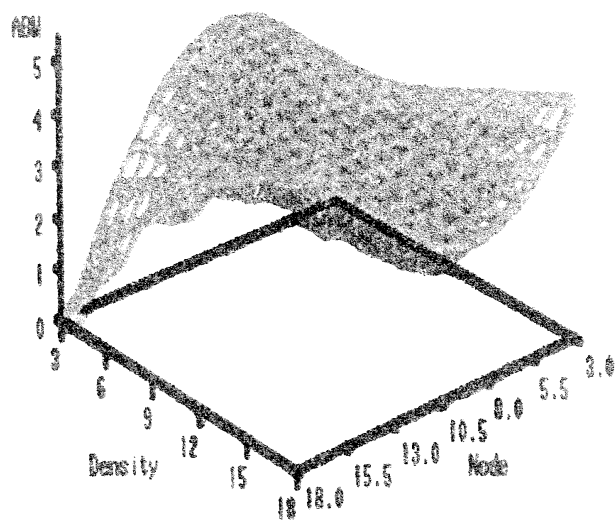

